\title{
Cattle Use on Summer Foothill Rangelands in
}

\section{Northeastern Oregon}

\section{RICHARD F. MILLER AND WILLIAM C. KRUEGER}

Highlight: The importance of several plant communities for summer cattle range was evaluated. Based on understory produc tion, eight communities were separated into three groups, i.e., bunchgrass, forested, and clearcut forested. Forested communities that had been clearcut and seeded to forage were the most productive. Soil depth and canopy cover were dominant environmental factors determining understory production on the study area. These two variables accounted for $96 \%$ of the variability in understory production. Clearcut forested communities seeded to forage provided $63 \%$ of the forage consumed by cattle and made up $31 \%$ of the study area. Seeded grasses accounted for 55\% of the cattle diet. Environmental factors highly correlated with utilization by cattle during the summer were distance to salt and water, soil depth, and canopy cover. Relations of soil depth and canopy cover were a result of their influence on plant growth. There appeared to be no direct forage competition between big game and cattle when livestock were present during the last half of summer.

Forested foothills in northeastern Oregon have been used as summer cattle (Bos taurus) range for many years. Besides providing an important forage resource for livestock, these lands also provide timber, water, recreation, wildlife, and fish.

Authors are, respectively, graduate research assistant and leader, Rangeland Resources Program, Oregon State University, Corvallis.

Miller's current address is Department of Animal, Range, and Wildlife Sciences, New Mexico State University, Las Cruces.

The article was submitted as Technical Article No. 4072, Oregon Agricultural Experiment Station, Corvallis. Cooperation of Dr. Martin Vavra, Eastern Oregon Experiment Station, is acknowledged.

Manuscript received August 1, 1975.

Understanding relationships between animals and their environment is essential to effectively integrate land resource use. Specific objectives of this study were to determine understory production of each plant species and the amount utilized by cattle and big game, mule deer (Odocoileus hemionus hemionus) and Rocky Mountain elk (Cervus canadensis nelsonii), in important plant communities; to define environmental factors influencing use of different plant communities by cattle; to evaluate the importance of forest communities that had been clearcut and seeded to forage plants for summer cattle range; and to evaluate grazing interrelationships between big game and cattle.

\section{Study Area}

The study area was located in the foothills of the Wallowa Mountains in northeastern Oregon at the Eastern Oregon Experiment Station. Elevation ranged between 3,300 and 4,000 feet. Pumicite, a dacite, silt-size volcanic ash, was found in varying amounts in the soil series occurring throughout the study area (Strickler, 1965). Pumicite in the soil profile has a strong influence on the kinds and amount of vegetation present since it has a relatively high moisture holding capacity. Annual precipitation averages 25 inches, the bulk falling in the form of snow in winter.

Plant communities sampled are typical of those found in northeastern Oregon, eastern Washington, and northern ldaho. Habitat types present in the study area were ponderosa pine-bluebunch wheatgrass (Pinus ponderosa-Agropyron spicatum); ponderosa pine-snowberry (Pinus ponderosa-Symphoricarpos albus); Douglasfir-snowberry (Pseudotsuga menziesii-Symphoricarpos albus); Douglasfirninebark (Pseudotsuga menziesii-Physocarpus malvaceus); and grand fir-pachistima (Abies grandis-Pachistima myrsinites) as described by 
Daubenmire (1970) and Daubenmire and Daubenmire (1968). A Sandberg bluegrass-Kellogg onion (Poa sandbergii-Allium anceps) community was also important in the study area but it did not reflect any previously identified habitat type.

The grand fir-pachistima habitat type was represented by a grand firadenocaulon (Abies grandis-Adenocaulon bicolor) community. Also included in the study area was a 66-acre clearcut, logged in 1969 and broadcast burned and seeded to timothy (Phleum pratense), orchardgrass (Dactylis glomerata), blue wildrye (Elymus glaucus), tall oatgrass (Arrhenatherum elatius), smooth brome (Bromus inermis), and Dutch white clover (Trifolium repens) in 1970. Habitat types contained in the clearcut were ponderosa pine-snowberry, Douglasfirninebark, and grand fir-pachistima. Plant communities established in the clearcut were: Kentucky bluegrass-goatsbeard (Poa pratensisTragopogon dubius) in the ponderosa pine-snowberry habitat type; ninebark-timothy in the Douglasfir-ninebark habitat type; and timothy-orchardgrass in the grand fir-pachistima habitat type.

Cattle were stocked on a 360-acre pasture July 31, 1973. The herd was composed of 94 cows and 90 calves. The cattle were removed to wean calves on August 21; on August 27, 88 cows were stocked back on the pasture until September 12 .

\section{Methods}

Plant communities were delineated by frequency transects placed throughout the study area. Frequency of occurrence of plant species from 40 to 120 plots $(1 \times 2 \mathrm{ft})$ was recorded for each community. All plant species in each plant community were listed. Frequency data were used to help characterize the plant communities and identify habitat types.

Herbage production for all plant species was determined by the weight estimate method (Pechanec and Pickford, 1937) from thirty 4.8 $\mathrm{ft}^{2}$ circular plots in each community. Ten of these plots were protected by utilization cages (Brown, 1954). The weight estimate method was also used to determine utilization of each species in forty $4.8 \mathrm{ft}^{2}$ circular plots in each community. Eight belt transects 160 feet long and 4.4 feet wide were placed in each community to measure browse production. Annual growth was calculated from measurements of leader length which were converted to dry weight production. Percent of use of annual leader growth was estimated for browse occurring within the transects. Production and utilization measurements were made in March, May, July, September, and October. One-acre exclosures were built to separate deer and elk utilization from cattle utilization in six of the eight communities. Exclosures were not placed in the grand fir-adenocaulon or Sandberg bluegrass-Kellogg onion communities due to their limited size.

Cattle and big game diets were determined from utilization measurements. Livestock preference for each plant species was evaluated with a relative preference index (Van Dyne and Heady, 1965). This was a ratio between percent composition by weight of a plant in the animals' diet to percent composition by weight of the same plant on the range:

$$
\text { Relative Preference Index (RPI) }=\frac{\% \text { diet }}{\% \text { composition of forage }}
$$

Canopy cover of the tree overstory was measured on each production plot with a Type C forest densiometer (Lemmon, 1956). Soil surveys conducted on the study area in 1956 and again in 1965 were used to describe soil characteristics. ${ }^{1}$ Percent slope was measured with a hand level (Giles, 1971). Distances from the center of each stand to water and salt facilities were also measured.

Four statistical techniques were used to help interpret data. They were simple linear regression, multiple regression using the backstep technique, analysis of variance with a completely randomized design, and Duncan's new multiple range test. Throughout this paper the term significant refers to $P<0.05$.

'File Data, Oregon State University, Rangeland Resources Program.

\section{Results and Discussion}

\section{Forage Production}

Total production of herbaceous and shrubby species during the peak growing season in eight communities sampled was segregated into three groups. Production was significantly different between groups. Based on understory production and physiognomy these assemblages were clearcut forested, bunchgrass, and forested groups.

The most productive communities were those constituting the clearcut forest (Fig. 1). Plant communities in the clearcut were

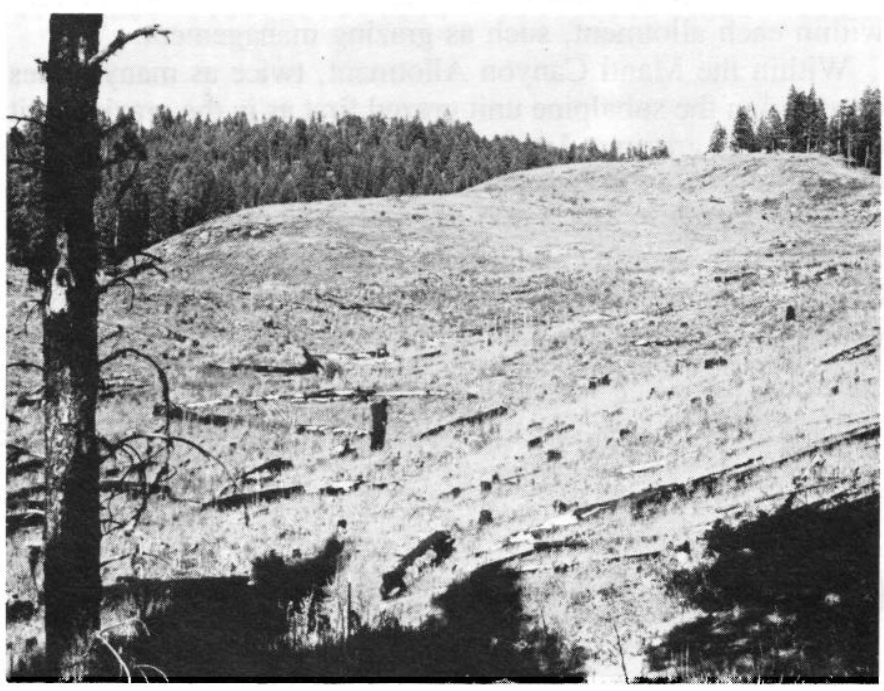

Fig. 1. The clearcut forest in 1973. Note differences in plant communities by change in aspect.

represented by Kentucky bluegrass-goatsbeard; ninebark-timothy; and timothy-orchardgrass. Total understory production ranged from 513 to $565 \mathrm{lb} / \mathrm{acre}$. The bunchgrass group was the second most productive (Fig. 2). These communities were

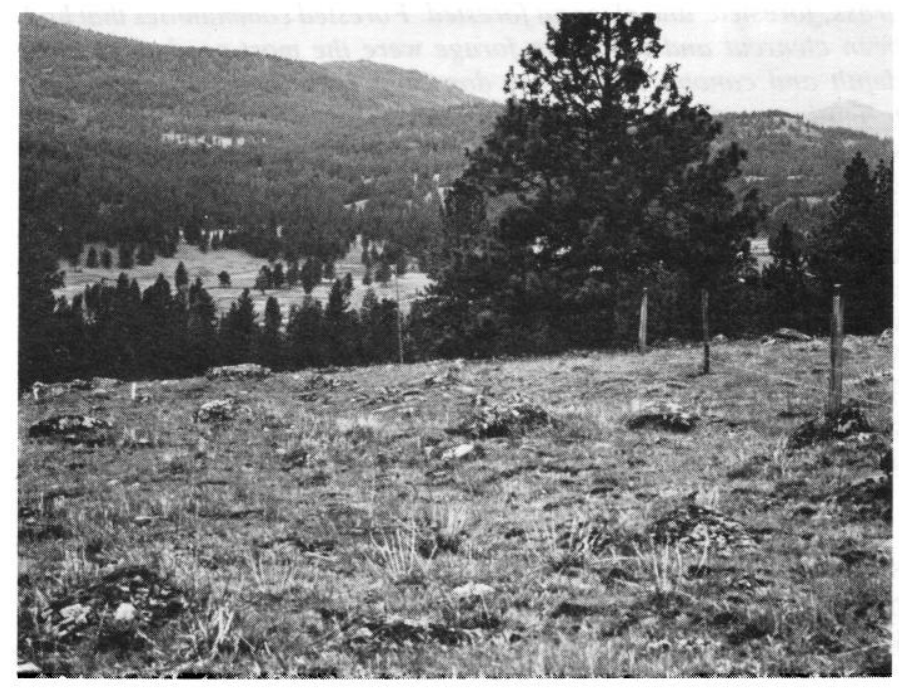

Fig. 2. A bunchgrass community in the foreground. The background shows a mixed coniferous forest on a north slope.

Sandberg bluegrass-Kellogg onion and ponderosa pine-bluebunch wheatgrass. They were located on shallow rocky soils with moderate to steep south slopes. Understory production averaged $312 \mathrm{lb} /$ acre with tree canopy cover averaging $4 \%$ or 


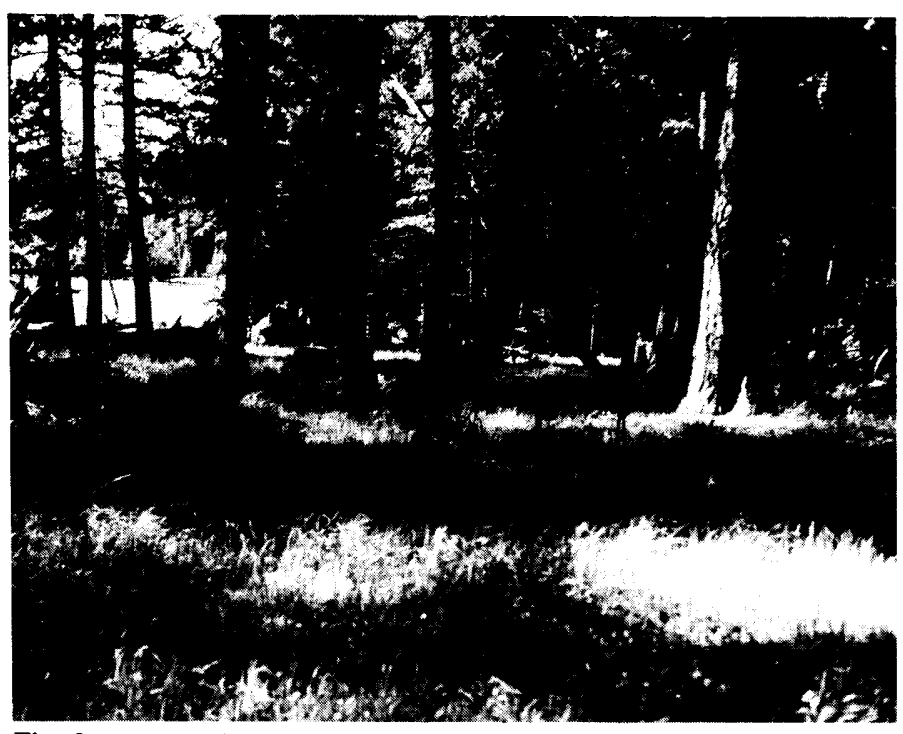

Fig. 3. Forested communities were on the best soils but produced the least amount of forage as a result of shading.

less. Forested communities produced the least amount of understory vegetation (Fig. 3). These communities-ponderosa pinesnowberry; Douglasfir-snowberry; and grand fir-adenocaulon-grew on deeper soils than the bunchgrass communities. Production ranged from $63 \mathrm{lb} /$ acre on the grand fir-adenocaulon community to $125 \mathrm{lb} /$ acre on the remaining two communities. Tree canopy cover ranged between 55 and $99 \%$.

Soil depth and canopy cover were the two most important environmental factors determining forage production on these foothill communities and accounted for $96 \%$ of the variability in understory production. Soil depth was assumed to be an indirect measure of soil water potential. Production of plant species requiring a moist environment increased with soil depth. Soil depth also interacted with canopy cover. On unlogged communities tree overstory had a linear coefficient of determination $\left(r^{2}\right)$ equaling 0.98 with understory production.

Forested sites had a high potential for producing forage after logging. The grand fir-pachistima habitat type had the greatest potential for producing seeded forage. Moisture availability was relatively high on these sites, and competition from previously established species was less than on other forested communities. Plant species established on these north slope sites prior to logging were low in density due to light interception by a dense tree overstory. Most species in these communities such as adenocaulon, twinflower (Linnaea borealis), and western meadowrue (Thalictrum occidentalis) are adapted to dense shade. With removal of the tree overstory they were unable to compete with seeded grasses. Orchardgrass, timothy, blue wildrye, tall oatgrass, and smooth brome constituted $69 \%$ of the vegetation on the logged grand fir-pachistima habitat type. Bull thistle (Cirsium vulgare) made up approximately $19 \%$ of production. Hedrick et al. (1971) found that mixcd coniferous forests which produced $100-200 \mathrm{lb}$ of forage per acre increased forage production tenfold after clearcutting and seeding to grass. If the clearcut is not seeded to grass, low value forages such as bull thistle naturally establish themselves (Pettit, 1968; Sassaman, 1972).

The site producing the least forage in the clearcut was the ponderosa pine-snowberry habitat type. Situated on a south exposure, this site was relatively more xeric than the Douglasfirninebark and grand fir-pachistima habitat types in the clearcut. Timothy was the most successful seeded species that became established, constituting $10 \%$ of the herbaceous layer. Seeded species made up $18 \%$ of the total vegetation on this site. Poor establishment was attributed to relatively lower moisture availability and heavier competition from previously established species than on other logged sites. Kentucky bluegrass established prior to logging made up $27 \%$ of the vegetation.

Establishment of seeded grasses was better on the moister Douglasfir-ninebark habitat type than on the ponderosa pinesnowberry habitat type, although competition from Kentucky bluegrass was still high. Seeded forages made up 33\% of the total production on this site. Timothy and orchardgrass accounted for $28 \%$ of production while Kentucky bluegrass represented $24 \%$. This ninebark-timothy community produced significantly more browse than any other community in the study area, averaging $21 \mathrm{lb} /$ acre annually. Ninety-five percent of this was ninebark.

Timothy and orchardgrass were the most successful introduced species in the clearcut. They represented $79 \%$ of the seeded forage production or $35 \%$ of the total vegetation occurring in the clearcut. Timothy and orchardgrass were also readily consumed by both livestock and big game.

\section{Utilization}

Utilization of forage by cattle was variable among communities. Forage use ranged from $4 \mathrm{lb} /$ acre in the grand firadenocaulon community to $209 \mathrm{lb} /$ acre on the timothy-orchardgrass community (Table 1). The heaviest levels of utilization by

Table 1. Forage removed (lb/acre) from each community by cattle.

\begin{tabular}{lc}
\hline \hline Plant communities & $\begin{array}{c}\text { Utilization } \\
\text { (lb/acre) }\end{array}$ \\
\hline Bunchgrass & 63 \\
$\quad$ Sandbcrg blucgrass-K cllogg onion & 41 \\
Ponderosa pine-blueb unch wheatgrass & \\
Forest & 20 \\
Ponderosa pine-snowberry & 8 \\
Douglasfir-snowberry & 4 \\
Grand fir-adenocaulon & \\
Clearcut forest & 56 \\
Kentucky bluegrass-goatsbeard & 63 \\
Ninebark-timothy & 209 \\
Timothy-orchardgrass & \\
\hline
\end{tabular}

cattle were in the seeded clearcut sites. The three logged sites provided $63 \%$ of the forage consumed by cattle and made up $31 \%$ of the study area (Table 2). The most important forages on these communities were seeded grass species. Seeded grasses

Table 2. Contribution (\%) of each community to total forage consumed by cattle, July 31 to Sept. 12, 1973.

\begin{tabular}{|c|c|c|c|c|}
\hline \multirow[b]{2}{*}{ Plant communities } & \multicolumn{4}{|c|}{ Percent forage consumed } \\
\hline & Grasses & Forbs & Browse & Total \\
\hline \multicolumn{5}{|l|}{ Bunchgrass } \\
\hline $\begin{array}{l}\text { Sandberg bluegrass-Kellogg onion } \\
\text { Ponderosa pine-bluebunch }\end{array}$ & 10 & 0 & 0 & 10 \\
\hline wheatgrass & 18 & 0 & 1 & 19 \\
\hline \multicolumn{5}{|l|}{ Forest } \\
\hline Ponderosa pine-snowberry & 3 & 0 & 1 & 4 \\
\hline Douglasf ir-snowberry & 3 & 0 & 1 & 4 \\
\hline Grand fir-adenocaulon & 0 & 0 & 0 & 0 \\
\hline \multicolumn{5}{|l|}{ Clearcut forest } \\
\hline Kentucky bluegrass-goatsbeard & 9 & 0 & 0 & 9 \\
\hline Ninebark-timothy & 18 & 0 & 1 & 19 \\
\hline Timothy-or chardgrass & 34 & 1 & 0 & 35 \\
\hline Total & 95 & 1 & 4 & \\
\hline
\end{tabular}


accounted for $55 \%$ of the cattle diet. Very few forbs remained on the study area by late summer. Browse made up only $5 \%$ of the understory composition. Cattle removed $52 \mathrm{lb}$ of herbaceous forage per acre on the bunchgrass communities. These communities provided $29 \%$ of the forage consumed and made up $28 \%$ of the study area. The most important species in the diet of cattle on bunchgrass communities were Sandberg bluegrass and bluebunch wheatgrass. Ten pounds of forage per acre were harvested by cattle on the forested communities. Although forested communities accounted for $41 \%$ of the study area, they provided only $8 \%$ of the total forage consumed by cattle. These results confirm earlier observations in this area that indicated variable preference for different plant communities made it difficult to obtain uniform utilization of forage. For example, cattle preferred open areas to dense forests (Hedrick et al., 1968; Pickford and Reid, 1948). Pickford and Reid (1948) also found open areas were grazed throughout summer, but forested ranges were grazed primarily in early summer in the Blue Mountains of Oregon. Other studies have indicated cattle use was influenced by forage availability (Mackie, 1970; Edgerton, 1971).

Environmental factors that accounted for most of the variability in pounds of forage harvested from a community by cattle were distance to water, distance to salt, soil depth, and percent tree canopy cover. The combined effect of distances to salt and water accounted for $79 \%$ of the variability in the amount of forage consumed by cattle. As distances to salt and water increased, forage use decreased. Canopy cover and soil depth appeared to relate indirectly with pounds of forage utilized by cattle. The additional effects of soil depth and canopy cover explained $99 \%$ of the variability in forage use. These two environmental factors strongly correlated with forage production in each community. The coefficient of determination in a simple linear regression between production and pounds utilization by cattle in each community equaled $74 \%$. Cook (1966) in his study of 21 factors associated with cattle distribution on mountain rangeland in Utah found location of water to be much more important than salt in their relation to forage utilization. He noted that percent slope, distance from water, thickness of brush, and the percent of palatable species on a site were the primary factors relating to utilization. We did not evaluate brush
Table 3. Percent composition of selected plant species in the diet of cattle and their relative preference index (RPD), July 31 to Sept. 12, 1973.

\begin{tabular}{lcc}
\hline \hline Species & Percent diet & RPI \\
\hline Grasses and sedges & & \\
Orchardgrass (Dactylis glomerata) & 28 & 2.4 \\
Timothy (Phleum pratense) & 16 & 1.7 \\
Kentucky bluegrass (Poa pratensis) & 71 & 1.5 \\
Sandberg bluegrass (Poa sandbergï) & 6 & 1.2 \\
Tall oatgrass (Arrhenatherum elatius) & 6 & 0.5 \\
Elk sedge (Carex geyeri) & 6 & 1.3 \\
Idaho fescue (Festuca idahoensis) & 5 & 2.3 \\
Blue wildrye (Elymus glaucus) & 4 & 1.8 \\
Bluebunch wheatgrass (Agropyron spicatum) & 2 & 2.6 \\
Field woodrush (Lazula campestris) & 2 & 0.8 \\
Ross sedge (Carex rosii) & 1 & 0.6 \\
Foxtail barley (Hordeum jubatum) & 1 & 0.7 \\
Smooth brome (Bromus inermis) & & \\
Browse & 1 & 0.7 \\
Shinyleaf spirea (Spiraea betulifolia) & 1 & 1.6 \\
Snowberry (Symphoricarpos albus) & 1 & 1.2 \\
Ninebark (Physocarpus malvaceus) & & \\
\hline
\end{tabular}

density as no brush stand was dense enough to restrict animal movement. Slope also had no significant influence on utilization. This range is not steep and few areas had a slope in excess of $15 \%$. We did not find percent of palatable species to influence utilization levels significantly during the mid-summer grazing season.

Only three plant species had preference indices greater than 2.0 during August and the first half of September (Table 3). These were orchardgrass, blue wildrye, and field woodrush (Luzula campestris). None of these exceeded a relative preference index rating of three. Influence of forage preference on diet selection was not pronounced during mid-summer to late summer.

Canada milkvetch (Astragalus canadensis) and prickly lettuce (Lactuca serriola) were highly palatable forbs but both made up only minute amounts of the vegetation composition. Forbs were most important in the vegetation composition during spring and early summer on these foothill rangelands. Very few remained by late summer.

Table 4. Contribution (\%) of important plant species to diets of cattle in mid-summer and big game in spring and early summer, and combined minimum and maximum levels of u tilization in the study area.

\begin{tabular}{|c|c|c|c|c|}
\hline \multirow[b]{2}{*}{ Species } & \multirow{2}{*}{$\begin{array}{l}\text { Percent } \\
\text { cattle diet }\end{array}$} & \multirow{2}{*}{$\begin{array}{c}\text { Percent } \\
\text { big game diet }\end{array}$} & \multicolumn{2}{|c|}{ Combined utilization (\%) } \\
\hline & & & Minimum & Maximum \\
\hline \multicolumn{5}{|l|}{ Grasses } \\
\hline Orchardgrass (Dactylis glomerata) & 28 & 6 & 7 & 48 \\
\hline Timothy (Phleum pratense) & 16 & 18 & 12 & 50 \\
\hline Kentucky bluegrass (Poa pratensis) & 11 & 1 & 6 & 33 \\
\hline Sandberg b luegrass (Poa sandbergii) & 7 & 6 & $\mathrm{t}$ & 31 \\
\hline Tall oatgrass (Arrhenatherum elatius) & 6 & 8 & $t$ & 6 \\
\hline Elk sedge (Carex geyeri) & 6 & 1 & 8 & 17 \\
\hline Idaho fescue (Festuca idahoensis) & 6 & 2 & $\mathrm{t}$ & 3 \\
\hline Blue wildrye (Elymus glaucus) & 5 & 2 & 4 & 19 \\
\hline Ross sedge (Carex rosii) & 2 & 1 & 1 & 30 \\
\hline \multicolumn{5}{|l|}{ Forbs } \\
\hline Goatsbeard (Tragopogon dubius) & 0 & 25 & $\mathrm{t}$ & 28 \\
\hline Tailcup lupine (Lupinus caudatus) & 0 & 2 & $\mathrm{t}$ & 10 \\
\hline Prickly lettuce (Lactuca serriola) & $\mathrm{t}$ & 2 & $\mathrm{t}$ & 3 \\
\hline \multicolumn{5}{|l|}{ Browse } \\
\hline Snowberry (Symphoricarpos albus) & 1 & 4 & 0 & 4 \\
\hline Ninebark (Physocarpus malvaceus) & 1 & 3 & 9 & 24 \\
\hline Oceanspray (Holodiscus discolor) & $\mathrm{t}$ & 2 & 14 & 38 \\
\hline Red stem ceanothus (Ceanothus sanguineus) & $\mathrm{t}$ & 1 & 30 & 54 \\
\hline
\end{tabular}




\section{Cattle and Big Game Diets}

Big game animals were present on the study area during winter, spring, and early summer. By mid-summer both elk and the majority of deer had moved to high elevation summer ranges. Only a few deer were present when cattle were stocked on the pasture July 31 . Although the presence of cattle and big game did not coincide, potential competition could occur from combined use on important forage species. Since big game and cattle used the range in different seasons, plant species composition at the time of grazing and therefore available forage was different for each of these animals.

Grasses and grass-like plants accounted for $95 \%$ of the cow and calf diet in mid-summer and $52 \%$ of the big game diet in spring and early summer. Many plant species overlapped in the diets of both cattle and big game (Table 4). Ninety-one percent of the grasses and sedges making up the diet of cattle were the same species as in $47 \%$ of the big game diet. The most important grass species found in both the diets of cattle, deer, and elk were orchardgrass, timothy, Sandberg bluegrass, and tall oatgrass. Although there was substantial overlap in diet composition between big game and cattle, over-utilization on forage species did not occur from the period of initial growth in the spring through fall at which time measurements were terminated. The most heavily grazed species were timothy and orchardgrass. These results agree closely with the work of Skovlin et al. (1968) in the Blue Mountains of Oregon.

No direct forage competition occurred between livestock and big game during the growing season on these foothill rangelands. However, cattle were present on the pasture only during the last half of summer. The impact that cattle and big game had on each other's forage resource may have been minimized by different seasons of use.

\section{Management Considerations}

Uniform utilization by cattle on foothill rangelands is difficult to obtain. Forage preference for different plant communities varies widely. Fencing these communities as individual units generally is impractical due to their limited size. A land manager can improve utilization on less preferred sites by strategically locating salt and water facilities. The distribution of clearcut forested communities that have been seeded to forage plants will also affect livestock distribution. Proper clearcut location may increase utilization of less preferred communities adjacent to the seeded clearcut forest. Interspersion of clearcuts with bunchgrass and forested range should increase use of these less preferred types as cattle graze among the more preferred clearcuts. However, if the manager wants to reduce levels of grazing on bunchgrass and forested ranges, cattle could be concentrated in a smaller area of the range if clearcuts were located in that portion of the range rather than interspersed throughout a large area. A great deal of flexibility in grazing programs can be developed by locating clearcuts properly. Specific grazing and forestry objectives can be integrated and met concerrently with correct distribution pat- terns of both forest practices and grazing.

Soil depth and plant species established prior to logging in a community will influence the success of establishment and production of seeded species. As soil depth increases, forage yields will also increase; but if the site has an established understory, introduction of new species through seeding will not greatly enhance total yield or carrying capacity. Deep soils are also the best timber producing sites. If clearcuts are seeded to forage plants, management programs to minimize interspecific composition will need to be implemented if reforestation is an objective of the land manager.

There appeared to be no direct forage competition between big game and cattle when livestock were present during the last half of summer. However, changes in season or intensity of use by big game or cattle could modify this. On these ranges careful monitoring of levels of utilization on key forage plants should indicate potential competition. As long as livestock do not overuse the range there should be adequate forage for big game.

\section{Literature Cited}

Brown, D. 1954. Methods of surveying vegetation. Commonwealth Bur. Pasture and Field Crop Bull. 24. 233 p.

Cook, C. W. 1966. Factors affecting utilization of mountain slopes by cattle. J. Range Manage. 19:200-204.

Daubenmire, R. 1970. Steppe vegetation of Washington. Wash. Agr. Exp. Sta. Pullman. Tech. Bull. 62. $131 \mathrm{p}$

Daubenmire, R., and J. B. Daubenmire. 1968. Forest vegetation of eastern Washington and northern Idaho. Wash. Agr. Exp. Sta. Pullman. Tech. Bull. 60. $104 \mathrm{p}$.

Edgerton, P. J. 1971. The effect of cattle and big game grazing on a ponderosa pine plantation. U.S. Dep. Agr., Forest Serv., Pacific Northwest Forest and Range Exp. Sta. Res. Note PNW-172.

Giles, R. H. (Ed.) 1971. Wildlife management techniques. The Wildlife Society. Washington, D.C. 633 p.

Hedrick, D. W., J. A. Young, J. A. B. McArthur, and R. F. Keniston. 1968. Effects of forest grazing practices on mixed coniferous forests of northeastern Oregon. Ore. Agr. Exp. Sta. Corvallis. Tech. Bull. 103. 24 p.

Hedrick, D. W., R. F. Keniston, and J. A. B. McArthur. 1971. Livestock and big game grazing on plantations in northeastern Oregon. Soc. Range Manage. 24th annual meeting, Reno, Nev. abstr. of papers. 22 p.

Lemmon, P. E. 1956. A spherical densimeter for estimating forest overstory density. Forest Sci. 2:314-320.

Mackie, R. J. 1970. Range ecology and relations of mule deer, elk, and cattle in the Missouri River Breaks, Montana. Wildl. Monogr. No. 20. 79 p.

Pechanec, J. F., and G. D. Pickford. 1937. A weight estimate method for the determination of range or pasture production. J. Amer. Soc. Agron. 29:894-904.

Pettit, D. R. 1968. Effects of seeding and grazing on a clearcut-burn in a mixed coniferous forest stand of the Wallowa Mountain Foothills. PhD Thesis. Oregon State Univ., Corvallis. $133 \mathrm{p}$.

Pickford, G. D., and E. H. Reid. 1948. Forage utilization on summer cattle ranges in eastern Oregon. U.S. Dep. Agr. Circ. 796. 27 p.

Sassaman, R. W. 1972. Economic returns from planting forage in national forests. J. Forest. 70:487-488

Skovlin, J. M., P. J. Edgerton, and R. W. Harris. 1968. The influence of cattle management on deer and elk. Trans. N. Amer. Wildl. Conf. 33: 169-181.

Strickler, G. S. 1965. Soil and vegetation on the Starkey experimental forest and range. Proc. Soc. Amer. Forest. 1965. p. 27-30.

Van Dyne, G. M., and H. F. Heady. 1965. Botanical composition of sheep and cattle diets on a mature annual range. Hilgardia. 36:465-492. 